\title{
The role of oxidative stress in small ruminants' health and production
}

\section{Pietro Celi ${ }^{1}$}

${ }^{1}$ Faculty of Veterinary Science, The University of Sydney.

ABSTRACT - This paper examines the role that oxidative stress plays in small ruminant medicine. We will examine how redox homeostasis is involved in some physiological functions and we will discuss the implications of the impairment of oxidative status on small ruminant health and production.

Key Words: health, oxidative stress, production, ruminants

\section{O papel do estresse oxidativo na saúde e produção de pequenos ruminantes}

\footnotetext{
RESUMO - Este artigo analisa o papel do estresse oxidativo sobre a medicina de pequenos ruminantes. Será examinado o envolvimento da homeostase redox em algumas funções fisiológicas e discutidas as implicações do comprometimento do estado oxidativo sobre a saúde ea produção de pequenos ruminantes.
}

Palvras-chave: estresse oxidativo, produção, ruminantes, saúde

\section{Introduction}

Oxidative stress is an active field of research in veterinary medicine and has been implicated in numerous disease processes including sepsis, mastitis, enteritis, pneumonia, respiratory and joint diseases (Lykkesfeldt \& Svendsen, 2007). A limited number of conditions in ruminant medicine have been investigated in regard to the effects of oxidative stress. Studies in cattle, sheep and goats have been sporadic and mainly with mastitis, pneumonia and retained placenta. More recently, studies have been focused on metabolic diseases that affect dairy ruminants during the peripartum period. With this in mind, it is the goal of this chapter to summarize the present knowledge of oxidative stress in ruminant physiology and to examine the basis of and evidence for the role of oxidative stress in ruminant health and production, highlighting the need for continued research on oxidative stress in ruminant medicine.

Oxidative stress in small ruminant physiology

Measuring oxidative stress

Oxidative stress in veterinary medicine and particularly in ruminant health is a relatively young field of research. Numerous and rapidly evolving methodologies for evaluating oxidative stress, each with their own distinct advantages and disadvantages, are available to clinician and scientists. However, differences in models and methodologies make it difficult to make meaningful comparisons, even for studies that seem quite similar. Methods for quantifying oxidative stress mostly include direct or indirect measures of oxidants and antioxidants. Given their often high reactivity, quantification of oxidants and antioxidants often requires specialized equipment and considerable experience. As oxidative stress is indicative of an imbalance between oxidants and antioxidants, methods for quantifying oxidative stress mostly include direct or indirect measures of oxidants and antioxidants (Miller et al., 1993; Lykkesfeldt \& Svendsen, 2007). In these sections, some principles and commonly used measures of oxidative stress and damage will be briefly outlined.

\section{Pro-oxidants}

The most abundant free radicals in biological systems are the oxygen-centred free radicals and their metabolites, usually referred as "reactive oxygen metabolites” (ROMs) (Miller et al., 1993). ROMs are formed continuously as normal by-products of cellular metabolism and, in low concentrations, they are essential for several physiological processes, including protein phosphorylation, transcription factors activation, cell differentiation, apoptosis, oocyte maturation, steroidogenesis, cell immunity and cellular 
defence against microorganisms (Miller et al., 1993; Dröge, 2002; Agarwal et al., 2005). However, when produced in excess, ROMs can damage cell functionality as they can harm cellular lipid, proteins, and DNA (Miller et al., 1993; Sugino, 2006).

Plasma level of ROMs is considered an indicator of free radical production (Miller et al., 1993). ROMs is a collective term that includes not only oxygen-centred free radicals such as superoxide anion and hydroxyl radical, but also some non-radical derivates of oxygen, such as hydrogen peroxide, and hypochlorous acid (Reilly et al., 1991). A ROMs kit has been developed to assess oxidant levels in plasma and other biological fluids. The ROMs test has been validated using electron spin resonance (Alberti et al., 2000) and is now considered the 'gold standard' for measuring total oxidative status. Electron spin resonance is not suitable for routine analysis as the method is complex and requires specific technical assistance not available in most laboratories. The utility of the ROMs assay in monitoring oxidative stress in goats (Di Trana et al., 2006; Celi et al., 2008; Celi et al.), sheep (Rizzo et al., 2008) and dairy cows (Pedernera et al., 2009; Bernabucci et al., 2002, 2005) has been reported.

The concentrations of individual oxidant components can be measured separately in the laboratory, but such measurements are time-consuming, labour intensive, and costly. It has been shown that free radical analytical system (FRAS 4) technology offers a quick, simple, precise and reliable method of assessing oxidative status in dairy cows (Merlo, 2008) and in horses (Celi et al., 2010c) which is particularly useful in the field where it is not always practical or possible to get samples to a laboratory immediately. The possibility of assessing oxidative stress directly in blood provides veterinarians with a simple and reliable method of measuring oxidative stress in clinical situations such as the monitoring of therapy and in the antioxidant supplementation of domestic animals. However, given the lack of reference values for ROMs in ruminants it is difficult to establish if and when these animals are experiencing oxidative stress. Therefore it is important to calculate the specific referral ranges because a correct biochemical evaluation of oxidative status is an essential premise to prevent and eventually to threat the effects of oxidative stress in ruminant medicine.

Advanced oxidation protein products (AOPP) are terminal products of proteins exposed to free radicals and arise from the reaction between plasma proteins and chlorinated oxidants mediated by a neutrophil enzyme myeloperoxidase (Fialovà et al., 2006; Noyan et al., 2006).
In humans, AOPP have been associated to several diseases like chronic renal failure (Witko-Sarsat et al., 1998), diabetes mellitus (Kalousová et al., 2002), diabetic nephropathy (Shi et al., 2008), coronary artery diseases (Kaneda et al., 2002), and obesity (Atabek et al., 2006). Chronic accumulation of AOPP has been demonstrated to promote inflammatory processes in diabetic kidney (Shi et al., 2008) and in chronic renal failure (Witko-Sarsat et al., 1998) indicating that AOPP might be a by-product of neutrophil activation during infections. Studies in ruminant have reported that higher levels of AOPP in lambs and dairy cows (Celi \& Raadsma, 2009) supplemented with Yerba Mate (Ilex Paraguanensis). More information about the role of protein oxidation in ruminants' health and production could be obtained by the comparison of AOPP with other indicators of protein oxidation, such as advanced glycation end products (AGE). However, while a correlation between AGE and inflammatory parameters is usually not found or is only weak, the induction of proinflammatory activities caused by AOPP seems to be more intense (Witko-Sarsat et al., 1999; Kalousová et al., 2005). This suggests that oxidative stress is closely linked to inflammation and acute phase reactions than advanced glycation process and its end products. AOPP could thus better describe acute inflammation, while AGE might serve more as a marker of chronic long-lasting damage (Kalousová et al., 2005). These observations are highly relevant as high level of AOPP could indicate the presence of inflammatory process which can compromise the correct embryonic development in dairy cow (Merlo, 2008; Merlo et al., 2008).

Lipids, in particular those that are polyunsaturated, are prone to oxidation. Lipids are one of the most susceptible substrates to free radicals damage and biomarkers of lipid peroxidation are considered the best indicators of oxidative stress (Georgieva, 2005). Malondialdehyde (MDA) is one of the several lowmolecular-weight end products formed during the radical induced decomposition of poly-unsaturated fatty acid (Janero, 1990). MDA readily reacts with thiobarbituric acid producing a red pigment which can be easily measured by spectrophotometry in the form of thiobarbituric acid reactive substances (TBARS) (Janero, 1990). It is worth noting that the MDA assays have been criticized for low specificity and artefact formation, since only a fraction of the MDA measured is generated in vivo. Furthermore, the thiobarbituric acid reactive substances (TBARS) assay, a common method used to measure MDA, is considered inaccurate, and returns 
results which differ according to the assay conditions used (Halliwell \& Chirico, 1993). For example, studies in dairy cows have yielded contrasting results with some reports failing to show any significant changes in plasma MDA concentrations during the peripartum period (Castillo et al., 2005; Castillo et al., 2006), while in other studies MDA or TBARS concentrations increased around calving (Bernabucci et al., 2002, 2005; Bouwstra et al., 2008). This apparent discrepancy could also have been mainly due to the great individual variations observed in MDA concentrations measured in the studies by (Castillo et al., 2005, 2006). Similarly, studies in transported cattle have failed to report a consistent change in MDA concentration. It seems that this discrepancy is partly due to the different methodologies employed to assess MDA. Thiobarbituric acid reactive substances detect a wide range of lipid peroxidation products, and are rather unspecific for MDA (Griffiths et al., 2002). High-pressure liquid chromatography would be expected to be highly specific, and perhaps, more accurate than the spectrophotometric procedures (Lykkesfeldt, 2001). More recently an ELISA based isoprostane, which are considered to be the most reliable markers of lipid oxidation (Milne et al., 2005), assay has become commercially available and might be able to shed more light on the role of lipid peroxidation during the peripartum period in ruminants.

\section{Antioxidants}

Endogenous antioxidants can be divided into three major groups (Miller et al., 1993). The first group comprises enzymatic antioxidants including superoxide dismutase (SOD) and glutathione-peroxidase (GSH-Px), and represents the main form of intracellular antioxidant defence. Plasma GSH-Px activity contributes to the oxidative defence of animal tissues by catalysing the reduction of hydrogen and lipid peroxides (Halliwell \& Chirico, 1993) and is also considered an indicator of oxidative stress (Tüzün et al., 2002). GSH-Px functions in cellular oxidation-reduction reactions to protect the cell membrane from oxidative damage caused by free radicals (Flohe et al., 1973). SOD catalyses the dismutation of superoxide to hydrogen peroxide $\left(\mathrm{H}_{2} \mathrm{O}_{2}\right)$ and it is considered the first defence against pro-oxidants (Halliwell \& Chirico, 1993). Studies in grazing sheep have shown that GSH-Px activity is influenced by soil and pasture characteristics (Andrés et al., 1997) and by season (Andrés et al., 1999). In dairy goats SOD activity is decreased during the postpartum period probably a consequence of lower peroxide generation as testified by the decrease in ROMs concentrations (Celi et al.). Since SOD activity increases $\mathrm{H}_{2} \mathrm{O}_{2}$ production, protection from reactive oxygen would only be given by a simultaneous increase in catalase and GSH-Px activities and availability of glutathione (Frei, 1994; Kehrer, 1994). Studies in dairy goats have shown that blood GSH-Px activity is decreased during the postpartum period, suggesting that goats may have experienced some degree of oxidative stress and lipid peroxidation (Celi et al., 2008). Since GSH-Px is directly targeted at removing $\mathrm{H}_{2} \mathrm{O}_{2}$ generated during the dismutation of free radicals (Dröge, 2002), it would reasonable to see a parallel decrease in ROMs levels. ROMs levels indeed, decreased o1hemically reactive sites and have strong reducing properties (Soriani et al., 1994; Moran et al., 2001). Studies in dairy goats have shown that plasma albumin concentrations are significantly reduced during summer (Di Trana et al., 2006). This finding is quite relevant considering that albumin is part of the antioxidant pool it being a free radical scavenger (Halliwell, 1988). Plasma albumin levels are also decreased during the peripartum period in dairy goats which further indicates that goats were exposed to oxidative stress during the peripartum period (Celi et al., 2008). Albumin is exclusively synthesized by the liver, and is the main source of plasma SH. The reduction in liver function that is usually observed in the early postpartum period might explain lower plasma $\mathrm{SH}$ and albumin levels. Studies in dairy cows have confirmed the antioxidant role played by albumin particularly near calving when animals usually do not receive any vitamin/ mineral supplementation (Castillo et al., 2005).

The third group is represented by the non-enzymatic low-molecular weight antioxidants, and it is found mainly in plasma but also in other extracellular and intracellular fluids. The primary antioxidant capacity of serum is derived from non-enzymatic antioxidants, such as glutathione, $\alpha$-tocopherol, $\beta$-carotene and uric acid (Halliwell \& Gutteridge, 1989). In particular, GSH plays an important role in protecting cells against oxidative stress and toxic agents. It acts as substrate or co-substrate in enzymatic reactions and it also reacts directly with free radicals and lipid peroxides (Briviba \& Sies, 1994).

For example, in a selenium deficiency situation, hepatic glutathione (GSH) synthesis is increased and this depletes cellular cysteine (Burk, 1983), so it may impair physiological processes (growth and wool production) where cysteine is required for protein synthesis. Indeed, GSH synthesis seems to compete with wool growth for cysteine (Liu \& 
Eady, 2005). Cysteine is vital for wool growth and is usually the first limiting amino acid for wool fiber synthesis (Liu \& Masters, 2000). Sheep selected for high wool production tend to have lower blood cysteine and GSH concentrations than those selected for low wool production (Hopkins et al., 1975; Williams, 1976). Low concentrations of GSH can be associated with impaired animal health as cysteine and GSH play a key role in the regulation of the immune response (Dröge et al., 1994). Therefore, considering that GSH is a reservoir of cysteine, selecting for both GSH concentrations and wool growth rate might result in improvements in both wool production and health status (Liu \& Eady, 2005). In the mean time, when selenium deficiency is diagnosed, its supplementation is recommended to improve the development of resistance and resilience of sheep to gastro intestinal parasites (Celi et al., 2010a).

Because of the difficulty in measuring each antioxidant component separately and their interaction in the plasma, several methods have been developed to assess total antioxidant capacity (TAC). The measure of antioxidant capacity considers the cumulative action of all the antioxidants present in plasma and body fluids, thus providing an integrated parameter rather than the simple sum of measurable antioxidants (Ghiselli et al., 2000). Antioxidant capacity can be measured by means of several methods, such as Trolox Equivalent Antioxidant Capacity (TEAC) (Miller et al., 1993), Total Radical-trapping Antioxidant Parameter (TRAP) (Ghiselli et al., 1995), Oxygen Radical Absorbance Capacity (ORAC) (Cao et al., 1993)), or the Ferric Reducing Ability of Plasma (FRAP) and Biological Antioxidant Potential (BAP) (Benzie \& Strain, 1996). The BAP test provides a global measurement of many antioxidants, including uric acid, ascorbic acid, proteins, $\alpha$-tocopherol and bilirubin (Benzie \& Strain, 1996). In dairy cows BAP levels have been measured during early lactation (Pedernera et al., 2009) and mid lactation (Celi \& Raadsma, 2010c), however, comparisons can be hardly done since those studies involved cows in different physiological phases. Also, the rearing system may determine important differences in terms of oxidative status of animals. Pasture-based system could improve oxidative status of animals due to the elevated antioxidants content of green grass (Gatellier et al., 2004; Descalzo et al., 2005) and the physical exercise related with grazing system, have better antioxidant status (Gatellier et al., 2004). Grazing may provide dairy cows with health benefits from certain vitamins and minerals. Vitamins A and E, and selenium are known antioxidants that play important roles in animal health and production. Though fresh forages are typically considered capable of supplying adequate levels of antioxidants for dairy cattle, the availability of these compounds for lactating grazing cows is diminished when pasture availability is not adequate to meet their energy requirements. In this situation the gap between energy required for milk production and energy intake is often met by supplementing cows with conserved forages like silage. Silage is known for its poor content in antioxidants (Ballet et al., 2000) and thus this might expose cows to oxidative stress. A decrease in BAP levels was observed when dairy cows were fed corn silage and concentrate supplementation (Celi \& Raadsma, 2009). Silage is known for its poor content in antioxidants (Ballet et al., 2000) and thus this might expose cows to oxidative stress. Concentrate supplementation with the diet has been proved to either reduce pasture intake (Bargo et al., 2002) and to increase the degradation of some antioxidants at ruminal level (Weiss et al., 1995). Plasma BAP might have decreased also as a direct consequence of ROMs increase. Indeed, changes in the components of antioxidants systems are often not the cause, but the consequence of the oxidative stress induced by higher free radical activity (Venditti \& Meo, 2006).

Plasma antioxidant status is the result of the interaction of many different compounds and systemic metabolic interactions (Ghiselli et al., 2000). As a single measure, TAC provides relevant information that may effectively describe the dynamic equilibrium between pro-oxidants and antioxidant in the plasma compartment (Cao \& Prior, 1998; Ghiselli et al., 2000). In absence of reference values for ruminants TAC can be used to evaluate the effect of treatments when the results are expressed as change with respect to the basal value (Ghiselli et al., 2000). Indeed, TAC is a useful tool for measuring stress in transported calves (Pregel et al., 2005). In conclusion the evaluation of TAC on a herd basis may be a useful indicator of animal welfare and may be more sensitive and reliable than the measure of a single parameter, which could reveal individual variations. Moreover, TAC could be used as a tool to evaluate the nutritional status of animals fed different diets or to evaluate the general nutritional status of animals throughout the year.

Oxidative stress in ruminant health

\section{Mastitis}

Mastitis is the most devastating disease of dairy animals, despite of improved management practices and dry cow therapy, mastitis remains worldwide problem of 
major economic threat to the dairy farmers. Inflammatory reaction accompanying mastitis is generally caused by bacterial infection. Severe inflammation damages the mammary secretory epithelium and cytotoxic radicals and proinflammatory cytokines are released by the phagocytic cells (Knaapen et al., 1999). Reactive nitrogen intermediates are important radicals that play complex role in inflammatory process (Goff et al., 1996). Excessive amounts of neutrophiles, macrophages, lymphocytes, eosinophiles and various epithelial cells of mammary tissue in milk is considered as a response of mammary tissue to microorganisms in part of inflammation of mammary gland (Smith, 1994; Knaapen et al., 1999). The level of some cytokines (TNF- $\alpha$, IL-1b, IL-6, IL-8) and other molecules such as nitric oxide (NO) are reported to increase during infections (Riollet et al., 2000; Notebaert et al., 2008).

Nitric oxide operates in a variety of tissues to regulate a diverse range of physiological processes, including the inflammatory response (Dawson \& Dawson, 1995). Macrophage and epithelial cells of the mammary gland produce significant amount of nitric oxide, this inducible nitric oxide mediates inflammation during mastitis (Bouchard et al., 1999). High nitric oxide activity has been observed in mastitic animals (Atakisi et al., in press) and an increase in milk nitric oxide levels from cows with experimentally induced mastitis has been reported, and it has been proposed that the elevated NO concentration in milk resulted from the inflammatory response of the mammary gland (Bouchard et al., 1999). An increase in NO concentrations in milk from mammary glands with subclinical mastitis also support the relationship between elevation of NO levels and inflammation (Atakisi et al., in press). Somatic cell count (SCC) in milk is a well known indicator reflecting mammary health and milk quality. A positive relationship between SCC and NO concentration has been reported ((Atakisi et al., in press; Bouchard et al., 1999). Changes in milk NO levels thus, could be proposed as an additional diagnostic tool to detect inflammation during mastitis. Finally, it has been noted that the concentrations of nitrite and nitrate increases both in plasma and milk after intramammary infusion of $E$. coli bacteria or E. coli endotoxin, (Blum et al., 2000; Komine et al., 2004) and that this increase can be prevented by treatment with aminoguanidine, a specific inhibitor of iNOS (Bouchard et al., 1999).

Nitric oxide production is increased during inflammatory diseases (Moilanen \& Vapaatalo, 1995; MacMicking et al., 1997) and it is activated by cytokines. Indeed, a positive correlation between intra-mammary and systemic TNF- $\alpha$ and NO production has been reported in an acute mastitis (Blum et al., 2000). Nitric oxide production is considered as a primer defence system (Huie \& Padmaja, 1993; Okamoto et al., 1997) as it has antimicrobial properties due to peroxynitrite, a reactive nitrogen metabolite, derived from oxidation of nitric oxide (Beckman et al., 1990), however, peroxynitrite can cause alterations in antioxidant balance in the organism when produced in excess (Chaiyotwittayakun et al., 2002). During inflammatory disease like mastitis, there is an increase in lipid peroxidation which causes a decrease in levels of some antioxidant molecules leading consequently to oxidative stress (Goff et al., 1996; Komine et al., 2004; Weiss et al., 2004). During inflammatory diseases, high levels of NO react with superoxide anions leading to formation of peroxinitrite radical (Beckman et al., 1990), and peroxinitrite radicals oxidize long chain fatty acids in cell membranes leading to increase in lipid peroxidation and formation of free radicals (Al-Sa'doni \& Ferro, 2000; Wang et al., 2002). Therefore, increase in lipid hydroperoxide level following lipid peroxidation during experimentally induced acute mastitis in cattle clearly indicates that mastitis causes formation of free radicals.

Milk from mammary glands with subclinical mastitis has higher levels of total oxidant capacity and lower levels of total antioxidant capacity compared to milk from mammary glands without subclinical mastitis (Atakisi et al., in press). An increase in ROMs following experimentally induced acute mastitis with lipopolysaccharide injection has been reported, however, a decrease in ROMS production was noted after retinoid administration (Gu et al., 2009). Therefore it seems that mastitis could induce oxidative stress leading to increase in formation of free radicals in milk

Serum and milk concentrations of ascorbate levels have also been identified as oxidative stress biomarkers in bovine mastitis. Dairy cattle affected by acute and subclinical forms of mastitis showed a significant decrease in ascorbate concentrations (Kleczkowski et al., 2005; Ranjan et al., 2005). This decrease in ascorbate concentration seems to be accompanied by an increase in the levels of lipid hydroperoxide in erythrocytes isolated from dairy cows with acute mastitis. The association of increased lipid peroxidation and lowered ascorbate levels further support that mastitis induced oxidative stress in mammary gland. Ascorbic acid is the most important watersoluble antioxidant in mammals (Sauberlich, 1994). It is well known that cows can synthesize vitamin $C$ and vitamin $\mathrm{C}$ is not a required nutrient for dairy cows, however several studies are suggesting that vitamin $\mathrm{C}$ is related to mastitis. 
Cows with mastitis have lower concentrations of vitamin C in the plasma and milk (Weiss et al., 2004; Kleczkowski et al., 2005) and the severity of clinical signs is proportional with the magnitude of the decrease in concentrations (Weiss et al., 2004). Subcutaneously injected vitamin C may have therapeutic value for cows with mastitis (Naresh et al., 2002; Ranjan et al., 2005), however, in LPS induced mastitic ascorbate administration had marginal effect on clinical signs but recovery of milk production was improved by the treatment (Chaiyotwittayakun et al., 2002). However, in view of the above mentioned results, it would be interesting to attempt the combined treatment of vitamin $\mathrm{C}$ and aminoguanidine to prevent the consequences of udder-related oxidative stress and inhibit inflammationinduced iNOS in mastitis (Lykkesfeldt \& Svendsen, 2007).

Antioxidant nutrition plays an important part in mastitis prevention because of the critical role of these micronutrients in mammary resistance to this disease (Smith et al., 1984; Erskine, 1993; Bowers, 1997; Weiss et al., 1997; Scaletti et al., 2003). Micronutrients that are associated with antioxidant activity including vitamin $\mathrm{A}$, vitamin $\mathrm{E}$, $\beta$-carotene, selenium, zinc, and copper have been studied for their effect on mastitis (Erskine, 1993; Bowers, 1997) and it has been reported that antioxidant supplementation could decrease the duration, incidence, and severity of clinical mastitis (Smith et al., 1984). In a study of experimentally induced acute mastitis, an increase in antioxidant capacity by administering vitamin $\mathrm{E}$ and selenium was reported (Mukherjee, 2008).Vitamin E and selenium given prior to calving have also been proposed for prophylactic treatment of mastitis, since vitamin $\mathrm{E}$ is depleted as calving approaches and remains low during weeks 1 and 2 of lactation (Smith et al., 1997). Pre-calving administration of vitamin $\mathrm{E}$ increased plasma á-tocopherol concentrations and neutrophils from vitamin E treated animals had a greater ability to kill bacteria (Hogan et al., 1993). Selenium, either alone or in combination with, vitamin E, increases bacterial killing by blood neutrophils (Hogan et al., 1990). GSH-Px is the selenoenzyme and it has been observed that blood concentration of selenium and GSH-Px activity negatively correlated with the prevalence of intramammary infection (Erskine et al., 1987). Low GSHPx activity in mastitic cows with high somatic cell counts and high level of prostaglandin formation has been recorded (Hogan et al., 1993). GSH-Px is the selenoenzyme and it has been observed that blood concentration of selenium and GSH-Px activity negatively correlated with the prevalence of intramammary infection (Erskine et al., 1987). These data further corroborate the involvement of oxidative stress in mastitis.

\section{Reproductive disorders}

In human medicine, there is growing evidence on the effects of oxidative stress in the female reproduction (Agarwal et al., 2005). ROMs can affect a variety of physiological functions in the reproductive tract, and excessive levels can result in precipitous pathologies affecting female reproduction. In ruminants and in the dairy cow in particular, oxidative stress has been associated with several pathological conditions, such as retained placenta, udder oedema, mastitis, which in turn may impair reproductive performances. The role of oxidative stress in the control of female reproduction has not been fully elucidated in ruminants, however it seems that pro and antioxidants can influence the reproductive axis at different levels.

ROMs are produced in the steroidogenic cells and mononuclear phagocytes in the corpus luteum and the increase in ROMs in the corpus luteum seems to be involved in luteolysis (Kato et al., 1997; Sugino, 2006). For instance, a decline in expression of SOD, as well as catalase, occurs during apoptosis in regressed corpus luteum of the bovine ovary (Rueda et al., 1995). Although ROMs have been implicated as both positive and negative regulators of luteal cell steroidogenesis (Carlson et al., 1993), it has been proposed that uncontrolled generation of ROMs, such as that elicited by PGF2 $\alpha$ (Sawada \& Carlson, 1994), disrupts cellular homeostasis leading to functional and structural luteolysis. Data supporting a role for ROMs in the loss of progesterone synthesis are derived from numerous studies of the effects of oxidative stressors and antioxidant factors on luteal cell steroidogenesis in vitro (Musicki et al., 1994; Vega et al., 1994). Furthermore, PGF $2 \alpha$-induced accumulation of ROMs occurs before the decrease in progesterone synthesis (Sawada \& Carlson, 1991), suggesting a direct cause-effect relationship. In addition, ROMs have been reported to inhibit progesterone synthesis by the inhibition of cytochrome P450, intracellular transport of cholesterol to mitochondria, and by impairing luteinizing hormone receptors (Sugino, 2006). Considering that ROMs are generated in the corpus luteum and that SOD activity has been reported in the corpus lutem, it is reasonable to speculate that ROMs and SOD are involved in the regulation of the corpus lutem function. When an imbalance between oxidants and antioxidants, as in oxidative stress, the corpus luteum activity can be impaired leading to premature luteolysis (Sugino, 2006). Indeed, ROMs can disrupt the integrity of luteal cells plasma membrane, which is often seen in the regression of the corpus lutem. The increase in ROMs during the 
regression phase of the corpus lutem could be ascribed to the decrease in SOD expression observed in the corpus lutem of pseudopregnant rats after PGF2 ${ }_{\alpha}$ administration (Shimamura et al., 1995). Also PGF2 $\alpha$ may contribute to ROMs increase since it induces lipid peroxidation (Shimamura et al., 1995) and stimulates superoxide radical production (Tanaka et al., 2000). Also macrophages have been hypothesized to be involved, at least in part, in luteolysis. Macrophages produce ROMs and damage cells when they are activated. They increase in number in the regressing corpus luteum and produce cytokines that inhibit P4 production by luteal cells (Sugino, 2006). In addition, a decrease in blood flow occurs in the ovary during the corpus luteum regression and this may cause tissue damage via reactive oxygen species generation by the mechanism of ischemia-reperfusion injury (Sugino, 2006).

Finally, ROMs are generated during normal embryo metabolism but an excess in ROMs production that occurs during oxidative stress has been reported to impair embryo development leading often to embryo death (Guerin et al., 2001). Embryos have internal (SOD and GSH-Px) and external (transferrin, ascorbic acid present in the oviduct) mechanisms to protect themselves against ROMs attack as well to dispose of ROMs excess (Guerin et al., 2001). However, due to continuous and abundant ROMs production during embryo development, OS may occur. ROMs can damage preimplantation embryos by increasing lipid peroxidation (Guerin et al., 2001) and DNA fragmentation (Takahashi et al., 2000), by altering either enzymes or mitochondrial structures and functions, and leading often to embryonic death (Guerin et al., 2001; Agarwal et al., 2005).

Oxidative stress might also be considered one of the mechanisms that link inflammation with embryo mortality. For example, observations from cows experiencing mastitis suggest that activation of inflammatory or immune responses can lead to embryonic mortality (Hansen et al., 2004). These embryonic losses appear to follow activation of multiple pathways that disrupt the reproductive axis at several points including the hypothalamic-pituitary axis, ovary, oocyte and the embryo (Hansen et al., 2004). Activation of inflammatory and immune responses leads to an increase in cytokines production, which in turn can increase secretion of other molecules detrimental for embryo survival and development, such as PGF $2_{\alpha}$ or nitric oxide (Hansen et al., 2004). Elimination of bacterial infections through phagocytosis involves activation of neutrophils which, once activated, undergo the respiratory burst releasing ROMs intended to target foreign pathogens, but the lack of specificity in these reactions may result in tissue damage to the host (Lykkesfeldt \& Svendsen, 2007).

Oxidative stress during pregnancy has been reported in cases of intrauterine growth restriction (IUGR) (Biri et al., 2007) and the situation is worsened in response to both underfeeding (Castillo et al., 2005) and overfeeding (Cole, 1990). A consequence, a reduction in the bioavailability of tetra-hydrobiopterin $\left(\mathrm{BH}_{4}\right)$, an essential factor for endothelial NO synthesis and a potent antioxidant, and nitric oxide in maternal and foetal tissues, develops (Shi et al., 2004). This may contribute to insulin resistance during late gestation, because NO mediates the stimulatory effect of insulin on muscle glucose uptake and metabolism (Jobgen et al., 2006). The recognition of oxidative stress in IUGR has led to the development of selective interventions. For example, dietary supplementation of selenium could enhance placental angiogenesis and foetal growth in underfed ewes (Reynolds et al., 2005). This effect may result, in part, from an increase in the bioavailability of $\mathrm{BH}_{4}$ and nitric oxide in the vascular system through an increase in the activity of seleniumdependent glutathione peroxidases to remove hydrogen peroxide (Shi et al., 2004; Wu et al., 2004). Finally, increasing the biological availability of $\mathrm{Zn}, \mathrm{Cu}$, and $\mathrm{Mn}$ through attachment to short-chain peptides has been reported to improve reproductive performance of swine, partly by enhancing antioxidant functions (Hostetler et al., 2003). Moreover, it is well known that immune cells generate large amount of ROMS when stimulated (Noyan et al., 2006; Lykkesfeldt \& Svendsen, 2007; Spears \& Weiss, 2008). At the moment, the reciprocal role of each actor in respect to the others is far from being elucidated. Several pathways might be activated but a central role of oxidation products seems likely.

In sheep early embryonic mortality is the main source of reproductive wastage (Celi \& Bush, 2010). This high embryonic mortality rate has enormous economic implications, increasing reproductive wastage and retarding genetic progress. The high rate of pregnancy failure is assumed to be a consequence of insufficient communication between the conceptus and the maternal environment. Biomarkers of oxidative stress seem to be involved in this network (Celi et al., 2010b). The oxidant status can influence early embryo development by modifying the key transcription factors and hence modifying gene expression (Dennery, 2004). Concentrations of ROMs may also play a major role both in the implantation and fertilization of eggs (Sharma \& Agarwal, 2004). There is an increased interest to examine 
the role of oxidative stress in female reproduction because it may be a major link in the infertility puzzle. Oxidative stress modulates a range of physiological functions and its role in pathological processes affecting the female reproduction. It is important to further elucidate the role of oxidative stress in infertility and embryonic losses in sheep and thus design strategies to overcome its adverse effects. Strategies to overcome oxidative stress are aimed at minimizing the exposure of gametes to environments that generate free radicals. Spermatozoa are the exogenous source of ROMS and therefore they can play an active role in the regulation of the reproductive tract microenvironment.

Oxidative stress can also affect reproductive events though reactive nitrogen species like nitric oxide (Rosselli et al., 1998). An endogenous nitric oxide system exists in the fallopian tubes (Rosselli et al., 1996). Nitric oxide has a relaxing effect on smooth muscles and it has similar effects on tubular contractility. Deficiency of nitric oxide may lead to tubal motility dysfunction, resulting in retention of the ovum, delayed sperm transport and infertility. Infertility associated with urogenital tract infections is associated with diminished sperm motility and viability. Increased nitric oxide levels in the fallopian tubes are cytotoxic to the invading microbes and also may be toxic to spermatozoa (Rosselli et al., 1995). In addition, nitric oxide might participate in the regulation of uterine contraction (Norman et al., 1999). Indeed, a decrease in antioxidants may contribute to impaired muscle tone and thus uterine contractibility. This can result in decreased transport of sperm to ova or retained placenta (Miller et al., 1993). In normal fertile woman, the contractions increase throughout the proliferative and periovulatory phases, and decrease in the secretory phase. From this point, nitric oxide is synergistic with progesterone and might relax uterine contraction in the secretory phase in a paracrine fashion. Studies on the effect of oxidative stress in the regulation of the reproductive physiology in sheep are lacking.

Therefore it seems that oxidative stress is involved in several events that occur in the maternal reproductive tract. The precise mechanisms by which oxidative stress regulates the physiology of reproduction are still not clear. Therefore we need to investigate the role that oxidative stress plays in the control of reproductive events in sheep. Clarity in the understanding of these processes will lead to the improvement on assisted reproductive technologies. Further characterization of components involved in maternal-embryo communication will lead to the identification of these factors. This will allow strategies to be devised that will reduce early embryonic and economic losses.

\section{Parasitic infections}

Parasitic diseases seem to be a causative source of oxidative stress, indeed, several studies have reported on the presence of oxidative stress in humans and animals infected with parasites (Selkirk et al., 1998; Upcroft \& Upcroft, 2001) as well as the antioxidant defense mechanism that exists between parasites and the mammalian host (Turrens, 2004). In human allergic inflammatory diseases, such helminthic infections, the associated influx of eosinophils has been implicated as a primary source of tissue damage (Corrigan \& Kay, 1992), possibly via their potent ROMs production (Petreccia et al., 1987; Yamashita \& Someya, 1987). Ruminant gastrointestinal nematode infections are common and widespread, and their immuno- pathology closely resembles that of human gastrointestinal infection. However, research on intestinal parasites linking to oxidative stress in ruminants is still scarce.

The responsiveness to nematode infection varies considerably between ruminant species, with goats being markedly more susceptible and less capable of developing immune resistance than sheep (Huntley et al., 1995; Woolaston \& Baker, 1996; Hoste et al., 2008). A marked species differences in antioxidant status have been observed between sheep and goats and it seems that these differences were influenced by nematode infection (Lightbody et al., 2001). Moreover, an intriguing relationship emerged between antioxidant status and differences in the relative susceptibility of sheep and goats to nematode infection. Compared with sheep, goats have higher plasma concentrations of albumin, SH groups, vitamins E and A, and TAC (Lightbody et al., 2001). It seems thus, that the effect of nematode infection on total antioxidant status reflects increases in oxidative stress related to intestinal nematode infection. As goats have evolved as browsers, they are less likely than sheep (grazers) to be exposed to parasitic larvae (Torres-Acosta \& Hoste, 2008). Therefore goats might have been under less evolutionary pressure to develop natural resistance to gastrointestinal parasite infections. Therefore the higher antioxidant status in goats might allow them to counteract the potentially greater oxidative challenge in response to gastrointestinal parasite infection (Lightbody et al., 2001).

The nutritional status of the host can influence the rate of acquisition of immunity to parasitic infection 
(Coop \& Holmes, 1996) and a better understanding of the role of nutrition will be important if producers are to make better use of the host acquired immunity and reduce dependence on anthelmintics (Van Houtert \& Sykes, 1996). The role of selenium is of particular relevance especially in selenium deficient areas. Sheep produced and run in these areas are more susceptible to diseases and infection due to immunodeficiency (Robson \& Plant, 2007). With escalating anthelmintic resistance, it is critical that more integrated approaches to parasite control are investigated.

Selenium is an essential element in the diet of animals and is important in host antioxidant defense and immune function (Rivera et al., 2003; Smith et al., 2005). A deficiency can result in ill thriftiness, reproductive losses, reduced reproductive efficiency, wool yields and reduced growth rate in young lambs throughout the growing period (Whelan et al., 1994; Rivera et al., 2003; Robson \& Plant, 2007) and a severe selenium deficiency can lead to sudden death from white muscle disease (White \& Rewell, 2007). Selenium is a component of the selenoenzyme glutathione peroxidase (GSH-Px), which acts as an antioxidant and helps prevent tissue damage caused by free radicals. GSH-Px has been used as an indicator of selenium status in animals due to the high correlation found between dietary selenium and the activity of this enzyme in plasma and red blood cells (Andrés et al., 1999).

A deficiency in selenium has been reported to cause delayed adult worm expulsion and increased egg production of established female worms in mice inoculated with the gastrointestinal parasite Heligmosomoides polygyrus, suggesting an impaired intestinal response in the mice (Smith et al., 2005). No differences in the overall immune response to Haemonchus contortus infection have been observed in sheep given an intraruminal selenium pellet (Jelinek et al., 1988). Selenium supplementation on helminthes burdens of marginally selenium deficient suckling Angora goat kids did not influence the level of parasitism (Fivaz et al., 1993). It seems then that selenium supplementation may not offer a useful additional means of controlling internal parasites of Angora goat kids. However, other studies have demonstrated that both selenium and vitamin $\mathrm{E}$ are required for specific IL-4-related changes in intestinal physiology that promote host protection against gastrointestinal nematode parasites in mice (Au et al., 2005; Smith et al., 2005).

In selenium supplemented sheep lower faecal egg counts than the non supplemented counterparts have been observed, which suggests the selenium status of sheep may influence the rate of acquisition of resistance to parasitic infection (Celi et al., 2010a). The observed negative correlation between faecal egg counts and GSHPx suggests that an increase in GSH-Px activity may reduce parasitic infection. However as the correlation was not very strong it is likely that selenium status is not the only factor responsible for the development on resistance to gastro intestinal parasites in Merino sheep (Celi et al., 2010a). Indeed, there are a number of other factors that can also play a role in the development of resistance and resilience to gastro intestinal parasites such as age, climatic conditions, genetics, nutrition and grazing management (Colditz et al., 1996; Van Houtert \& Sykes, 1996; Burke et al., 2009). Further evaluation of the contribution of selenium to worm expulsion should contribute to both an understanding of the role of oxidative stress in the development of resistance to gastro intestinal parasites.

Oxidative stress in ruminant metabolism and production

\section{Metabolic changes mediated by ROMs}

Impairment of animal performance by ROMs may involve altered metabolism as much or more than actual cell damage. ROMs are involved in numerous signalling pathways (Dröge, 2002) and some of these are involved in the control of anabolic and catabolic processes. For example, proteins that are sensitive to oxidative damage often react with ROMs through redox-active cysteine residues and because these cystein residues undergo similar oxidative modification in response to oxidative changes in SH groups' redox status, disease related changes in redox status may cause disruption of those physiological responses (Dröge, 2006). Both antioxidant defense and reactions catalysed by steroidogenic enzymes require reducing equivalents provided by NADPH (Liebler, 1993; Perl et al., 2002). Excessive consumption of reducing equivalents by oxidative stress can lower $\mathrm{NADPH}_{2}$ and increase NADP concentrations despite elevated activity of the monophosphate shunt, which generates the reduced form (Kehrer \& Lund, 1994). Consumption of reducing equivalents by ROM reactions can diminish the supply of NADPH available for important physiological processes. Finally, the induction of the monophosphate shunt by increased ROM imbalance can divert glucose from other pathways. This possibility assumes greater importance when the requirement for glucose and the quantity available in the ruminant are considered. In dairy cows, pregnancy and lactation are physiological stages considered to induce metabolic stress (Drackley, 1999). Dairy cows can 
experience oxidative stress (Pedernera et al., 2009; Bernabucci et al., 2005; Castillo et al., 2006), which may be associated with metabolic diseases during the peripartum period (Miller et al., 1993). A number of recent studies have reported variable levels of oxidative stress during the peri-parturient period in dairy cows (Bernabucci et al., 2005; Castillo et al., 2005; Gaál et al., 2006) and It seems that ROMs and anti-oxidants may be involved in some relevant physiological functions such as milk yield (Gabai et al., 2004). The adoption of intensive methods of husbandry in dairy ruminants for higher milk yields is likely to increase the incidence of metabolic diseases. The study of the metabolic and nutritional factors that affect the oxidative status in ruminants is an interesting area of research and there is growing body of evidence underpinning the patho-physiological consequences of oxidative stress in farm animals. The animal feed industry is under increasing consumer pressure to reduce the use of antibiotics as feed additives. This is a natural consequence of the increasing demand of safe products for human consumption. The use of herbs as additives in livestock nutrition, as an alternative to other chemical compounds, is a new goal in livestock production (Makkar et al., 2007). The use of alternative feedstuff naturally rich in antioxidants, in ruminant nutrition represents a novel management tool that is green, clean, ethical (Martin, 2006) and extremely easy to use. However, the effect of dietary antioxidant supplementation in ruminants has not yet been fully evaluated and thus, the role and the activity of natural antioxidants not commonly present in the diets of ruminants warrants further investigation.

\section{Milk production}

In the post-partum period, cows are metabolically challenged as energy demands outstrip energy intake, and animals enter a state of negative energy balance (Ingvartsen and Andersen, 2000). This triggers mainly catabolic pathways which, at the cellular level, increase the production of ROMs (Bernabucci et al., 2005). There is evidence that oxidative stress is affected by body condition at calving (Bernabucci et al., 2005) and by milk yield (Lohrke et al., 2004; Castillo et al., 2006) and diet (Gabai et al., 2004). Cows with a body condition score of greater than 3 before calving mobilize more body reserves in the post-partum period and experience more oxidative stress than animals with lower scores (Bernabucci et al., 2005). Cows with high milk yields have higher concentrations of oxidative stress than lower yielding animals (Lohrke et al., 2004; Castillo et al., 2006) and the feeding of high levels of starch to cows during early lactation increases oxidative stress, possibly due to changes in oxidative phosphorylation (Gabai et al., 2004).

In cows fed two different diets designed to achieve restricted or high milk production, the concentration of antioxidants was low and the concentration of ROMs high in the first 2 weeks of lactation in both groups (Pedernera et al., 2009). The concentration of antioxidants was lower during early lactation, in agreement with other reports (Goff \& Stabel, 1990; LeBlanc et al., 2004), and is presumably due, in part, to the utilization of antioxidants in colostrums production (Goff \& Stabel, 1990). Changes in free radical and antioxidant concentration appear to represent homeorhetic processes that normally occur in early lactation, although these were higher in the fed restricted cows (Pedernera et al., 2009). Given the lack of reference values for ROMs and BAP in cows, and the fact that few studies have been carried out in this area the causes of oxidative stress are difficult to identify. Therefore, medium and high energy balance and milk yield categories have been developed to further investigate the relationship between these variables and oxidative stress (Pedernera et al. 2009). This approach reduces the effect of individual cow variation and also takes into account the effect of the feeding system. For the energy balance category, the results indicated that an increased energy reserve mobilization affected the level of oxidative stress but only in cows fed to achieve restricted milk production. Cows fed to achieve restricted milk production had higher levels of OS and of NEB relative to cows fed to achieve high milk production. Oxidative stress levels were related to lower BAP concentrations in cows fed to achieve restricted milk production, a finding that might suggest that only cows with very high body reserve mobilization experience oxidative stress (Pedernera et al., 2009). Indeed, cows in good body condition at calving and in high negative energy balance in early lactation had higher oxidative stress (Bernabucci et al., 2005). Similarly in humans obesity is associated with high levels of pro-oxidants (Vincent et al., 2007). Therefore, the higher level of oxidative stress in cows in extreme negative energy balance might reflect a reduction in the precursors of endogenous antioxidants. Although milk production is associated with oxidative stress due to the increased cellular metabolism involved (Lohrke et al., 2004; Castillo et al., 2006), it has been found that oxidative stress was higher in cows fed to achieve restricted milk production or tended to be higher in cows fed to achieve high milk production when the yield was lower (Pedernera et al., 2009). The high level of oxidative stress in low-producing cows was associated with high 
concentrations of ROMs. Dairy cows are exposed to various metabolic pressures of adaptation to high milk yield and environmental conditions and oxidative stress may develop. It has been proposed that the activation of antioxidant defences is a preparative mechanism against oxidative stress caused by physiological stress situations (Hermes-Lima, 1988). It seems, indeed, that the entire antioxidant system is under homeostatic control. However, when metabolic reactions are overloaded, free radicals accumulate and the disturbance of the redox balance may occur, resulting in oxidative stress.

Also heat stress has been suggested to affect oxidative status in dairy ruminants which can affect reproductive and productive performances. Evidence suggests that the effects of elevated temperatures on embryonic development involve changes in the metabolism of free radicals. Heat shock increases intracellular ROMs in cultured bovine embryos, which in turn delays or blocks embryo development (Sakatani et al., 2008). Moreover, exposure of cultured mouse embryos to elevated temperatures causes a reduction in GSH (Aréchiga et al., 1995). The situation in vivo is still somehow controversial. No evidence of a beneficial effect of supplemental vitamin $\mathrm{E}$ and selenium above estimated requirements on reproduction or milk yield of lactating dairy cows under cool or heat stress conditions or of vitamin $E$ as an embryonic thermoprotectant or as a culture medium additive for enhancing development of preimplantation embryos in culture has been observed (Paula-Lopes et al., 2003). It is possible that supplementation of vitamin $\mathrm{E}$ and selenium are unlikely to enhance reproductive or lactational performance of lactating dairy cows receiving adequate dietary requirements of these nutrients.

Higher erythrocyte oxidant and antioxidant biomarkers in cows calving in summer than in cows calving in spring has been reported (Bernabucci et al., 2002), which would indicate some effects of hot weather on the oxidative status of transition cows. Also higher plasma ROMs concentrations has been reported in lactating dairy goats in summer compare to spring (Di Trana et al., 2006). In another study heat stress did not increase lipid peroxidation or lipid-soluble antioxidant concentrations in blood of lactating cows (Trout et al., 1998). However, the animals used in these studies were in different physiological status, which might be responsible for the discrepancies of the results. Overall, these results may suggest that the effects of heat stress on oxidative status are probably related to the physiological phase of the animals, and also that these effects might be different at local (embryonic development within the uterus) or systemic level (plasma oxidative stress biomarkers).

\section{Conclusions}

The field of oxidative stress in small ruminant medicine is still in the early stages of development. Despite oxidative stress has been associated with numerous conditions, there is a great deal to be discovered about its role in ruminant health and production. For example, if oxidative stress is a primary cause of pathologic change or a consequence of disease processes still remains to be determined. Clarity of understanding of the pathophysiology of oxidative stress in ruminants will allow designing specific antioxidant therapies. Future research should focus on the establishment of a reference panel of biomarker of oxidative stress to be used in veterinary medicine. Future research should also address the issue of standardization of techniques and methodologies to study oxidative stress. For example, tissue biopsy sampling techniques can be utilized only in particular cases in veterinary medicine, therefore a major challenge in veterinary oxidative stress research is to develop a set of blood biomarkers that can reliably reflect the tissue oxidative status in the individual animal. There are numerous techniques that can be used to measure oxidative damage (Lykkesfeldt \& Svendsen, 2007), however veterinary scientists and clinicians need to establish whether oxidative stress biomarkers measured in blood and/or serum provide a reasonable index of the general oxidative stress status.

Considering that oxidative damage is likely to occur in only few tissues at the same time, high levels of serum oxidative stress biomarkers can be the consequence of: 1 ) a generalized increase in oxidative stress in most of the tissues, resulting in an increase of the biomarker concentration in blood proportional to the extent of the tissues damage; 2 ) the increase of oxidative stress just in a particular tissue which is the origin of the pathological dysfunction; 3) an increase of oxidative damage produced specifically in the circulatory system (Argüelles et al., 2004). Even if several animal studies seems to suggest that oxidative stress biomarkers change toward the same direction in blood and tissues this needs to be fully evaluated in ruminant species. 


\section{References}

AGARWAL, A.; GUPTA, S.; SHARMA, R. Role of oxidative stress in female reproduction. Reproductive Biology and Endocrinology, v.28, n.3, 2005.

ALBERTI, A.; BOLOGNINI, L.; MACCIANTELLI, D. et al. The radical cation of n,n-diethyl-para-phenylendiamine : a possible indicator of oxidative stress in biological samples. Research on Chemical Intermediates, v.26, p.253-267, 2000.

AL-SA'DONI, H.; FERRO, A. S-Nitrosothiols: a class of nitric oxidedonor drugs. Clinical Science, v.98, p.507-520, 2000.

ANDRÉS, S.; JIMENEZ, A.; MAÑÉ, M.C. et al. Relationships between some soil parameters and the blood glutathione peroxidase activity of grazing sheep. The Veterinary Record v.141, p.267-268, 1997.

ANDRÉS, S.; MAÑÉ, M.C.; SÁNCHEZ, J. et al. Temporal variations in blood glutathione peroxidase (GSHPx) activity in sheep at pasture in a Mediterranean area. The Veterinary Journal, v.157, p.186-188, 1999.

ARÉCHIGA, C.F.; EALY, A.D.; HANSEN, P.J. Evidence that glutathione is involved in thermotolerance of preimplantation murine embryos. Biology of Reproduction, v.52, p.1296-1301, 1995. doi: 10.1095/biolreprod52.6.1296.

ARGÜELleS, S.; GARCÍA, S.; MALDONADO, M. et al. Do the serum oxidative stress biomarkers provide a reasonable index of the general oxidative stress status? Biochimica et Biophysica Acta (BBA) - General Subjects, v.1674, p.251259, 2004.

ATABEK, M.; KESKIN, M.; YAZICI, C. et al. Protein oxidation in obesity and insulin resistance. European Journal of Pediatrics, v.165, p.753-756, 2006.

ATAKISI, O.; ORAL, H.; ATAKISI, E. et al. Subclinical mastitis causes alterations in nitric oxide, total oxidant and antioxidant capacity in cow milk. Research in Veterinary Science (in press).

AU, Y.J.; SMITH, A.; ZHAO, A. Impact of vitamin E or selenium deficiency on nematode-induced alterations in murine intestinal function. Experimental Parasitology, v.109, p.201-208, 2005.

BALLET, N.; ROBERT, J.C.; WILLIAMS, P.E.V. Vitamins in forages. In: GIVENS, E.O.; AXFORD, R.F.E.; OMED, H.M. (Eds.) Forage evaluation in ruminant nutrition. Oxon: CABI Publishing, 2000. p.399-431.

BARGO, F.; MULlER, L.D.; DELAHOY, J.E. Milk response to concentrate supplementation of high producing dairy cows grazing at two pasture allowances. Journal of Dairy Science, v.85, p.1777-1792, 2002.

BECKMAN, J.S.; BECKMAN, T.W.; CHEN, J. et al. Apparent hydroxyl radical production by peroxynitrite: implications for endothelial injury from nitric oxide and superoxide. Proceedings of the National Academy of Sciences of the United States of America, v.87, p.1620-1624, 1990.

BENZIE, I.F.F.; STRAIN, J.J. The ferric reducing ability of plasma (FRAP) as a measure of "antioxidant power": the frap assay. Analytical Biochemistry, v.239, p.70-76, 1996.

BERNABUCCI, U.; RONCHI, B.; LACETERA, N. et al. Markers of oxidative status in plasma and erythrocytes of transition dairy cows during hot season. Journal of Dairy Science, v.85, p.2173-2179, 2002

BERNABUCCI, U.; RONCHI, B.; LACETERA, N. et al. Influence of body condition score on relationships between metabolic status and oxidative stress in periparturient dairy cows. Journal of Dairy Science, v.88, p.2017-2026, 2005.

BIRI, A.; BOZKURT, N.; TURP, A. et al. Role of oxidative stress in intrauterine growth restriction. Gynecologic and Obstetric Investigation, v.64, p.187, 2007.

BLUM, J.W.; DOSOGNE, H.; HOEBEN, D. et al. Tumor necrosis factor-[alpha] and nitrite/nitrate responses during acute mastitis induced by Escherichia coli infection and endotoxin in dairy cows. Domestic Animal Endocrinology, v.19, p.223-235, 2000.

BOUCHARD, L.; BLAIS, S.; DESROSIERS, C. et al. Nitric oxide production during endotoxin-induced mastitis in the cow. Journal of Dairy Science, v.82, p.2574-2581, 1999.

BOUWSTRA, R.J.; GOSELINK, R.M.A.; DOBBELAAR, P. et al. The relationship between oxidative damage and vitamin e concentration in blood, milk, and liver tissue from vitamin e supplemented and nonsupplemented periparturient heifers. Journal of Dairy Science, v.91, p.977-987, 2008.

BOWERS, T.L. Nutrition and immunity part 2: The role of selected micronutrients and clinical significance. Veterinary Clinical Nutrition, v.4, p.96-101, 1997.

BRIVIBA, K.; SIES, H. Non-enzymatic antioxidants defence system. In: FREI, B. (Ed.) Natural antioxidants in human health and disease. San Diego: Academic Press, 1994. p.107-128.

BURK, R.F. Biological activity of selenium. Annual Review of Nutrition, v.3, p.53-70, 1983.

BURKE, J.M.; MILLER, J.E.; TERRILL, T.H. Impact of rotational grazing on management of gastrointestinal nematodes in weaned lambs. Veterinary Parasitology, v.163, p.67-72, 2009.

CAO, G.; ALESSIO, H.M.; CUTLER, R.G. Oxygen-radical absorbance capacity assay for antioxidants. Free Radical Biology and Medicine, v.140, p.303-311, 1993.

CAO, G.; PRIOR, R.L. Comparison of different analytical methods for assessing total antioxidant capacity of human serum. Clinical Chemistry, v.44, p.1309-1315, 1998.

CARLSON, J.C.; WU, X.M.; SAWADA, M. Oxygen radicals and the control of ovarian corpus luteum function. Free Radical Biology and Medicine, v.14, p.79-84, 1993.

CASTILLO, C.; HERNANDEZ, J.; BRAVO, A. et al. Oxidative status during late pregnancy and early lactation in dairy cows. The Veterinary Journal, v.169, p.286-292, 2005.

CASTILLO, C.; HERNANDEZ, J.; VALVERDE, I. et al. Plasma malonaldehyde (MDA) and total antioxidant status (TAS) during lactation in dairy cows. Research in Veterinary Science, v.80, p.133-139, 2006.

CELI, P.; BUSH, D.R. Pregnancy, lambing and survival. In: COTTLE, D. (Ed.) International sheep and wool handbook. Nottingham University Press, 2010. p.223-257.

CELI, P.; DI TRANA, A.; QUARANTA, A. Metabolic profile and oxidative status in goats during the peripartum period. Australian Journal of Experimental Agriculture, v.48, p.1004-1008, 2008.

CELI, P.; RAADSMA, H.W. The effects of yerba mate (Ilex paraguarensis) supplementation on the productive performance of lambs. Ruminant physiology, digestion, metabolism, and effects of nutrition on reproduction and welfare. In: INTERNATIONAL SYMPOSIUM IN RUMINANT PHYSIOLOGY, 11., 2009, Clermont-Ferrand, France. Proceedings... Clermont-Ferrand, 2009. p.804-805.

CELI, P.; EPPLESTON, J.; ARMSTRONG, A. et al. Selenium supplementation increases wool growth and reduce faecal egg counts of Merino weaners in a selenium deficient area. Animal Production Science, v.50 (in press), 2010a.

CELI, P.; MERLO, M.; DA DALT, L. et al. Plasma advanced oxidised protein products (AOPP) as a novel indicator of late embryonic mortality in dairy cows. Reproduction, Fertility and Development, 2010b.

CELI, P.; RAADSMA, H.W. Effects of yerba mate (Ilex paraguariensis) supplementation on the productive performance of dairy cows during mid-lactation. Animal Production Science, v.50, 2010c (in press).

CELI, P.; SULLIVAN, M.; EVANS, D. The stability of the reactive oxygen metabolites (d-ROMs) and biological antioxidant potential (BAP) tests on stored horse blood. The Veterinary Journal, v.183, p.217-218, 2010c. 
CELI, P.; TRANA, A.D.; CLAPS, S. Effects of plane of nutrition on oxidative stress in goats during the peripartum period. The Veterinary Journal, v.184, p.95-99, 2010d.

CHAIYOTWITTAYAKUN, A.; ERSKINE, R.J.; BARTLETT, P.C. et al. The effect of ascorbic acid and l-histidine therapy on acute mammary inflammation in dairy cattle. Journal of Dairy Science, v.85, p.60-67, 2002.

COLDITZ, I.G.; WATSON, D.L.; GRAY, G.D. et al. Some relationships between age, immune responsiveness and resistance to parasites in ruminants. International Journal for Parasitology, v.26, p.869-877, 1996.

COLE, D.J.A. Nutritional strategies to optimize reproduction in pigs. Journal of Reproduction Fertility, v.40, p.67-82, 1990.

COOP, R.L.; HOLMES, P.H. Nutrition and parasite interaction. International Journal for Parasitology - Novel Approaches to the Control of Helminth Parasites of Livestock, v.26, p.951-962, 1996.

CORRIGAN, C.J.; KAY, A.B. T cells and eosinophils in the pathogenesis of asthma. Immunology Today, v.13, 501-507, 1992.

DAWSON, T.M.; DAWSON, V.L. Nitric oxide: actions and pathological roles. Neuroscientist, v.1, p.7-18, 1995.

DENNERY, P.A. Role of redox in fetal development and neonatal diseases doi:10.1089/152308604771978453. Antioxidants \& Redox Signaling, v.6, p.147-153, 2004.

DESCALZO, A.M.; INSANI, E.M.; BIOLATTO, A. et al. Influence of pasture or grain-based diets supplemented with vitamin $\mathrm{E}$ on antioxidant/oxidative balance of Argentine beef. Meat Science, v.70, p.35-44, 2005.

DI GIUSEPPE, D.; DI SIMPLICIO, P.; CAPECCHI, P.L. et al, Alteration in the redox state of plasma in heart-transplant patients with moderate hyperhomocysteinemia. Journal of Laboratory and Clinical Medicine, v.142, p.21-28, 2003.

DI GIUSEPPE, D.; FROSALI, S.; PRIORA, R. et al. The effects of age and hyperhomocysteinemia on the redox forms of plasma thiols. Journal of Laboratory and Clinical Medicine, v.144, 235-245, 2004

DI TRANA, A.; CELI, P.; CLAPS, S. et al. The effect of hot season and nutrition on the oxidative status and metabolic profile in dairy goats during mid lactation. Animal Science, v.82, p.717722, 2006.

DRACKLEY, J.K. Biology of dairy cows during the transition period: the final frontier. Journal of Dairy Science, v.82, 2259-2273, 1999.

DRÖGE, W. Free radicals in the physiological control of cell function. Physiological Reviews, v.82, 47-95, 2002.

DRÖGE, W. Redox regulation in anabolic and catabolic processes. Current Opinion in Clinical Nutrition \& Metabolic Care, v.9, p.190-195, 2006. doi: 110.1097/1001.mco.0000222098. 0000298514.0000222040 .

DRÖGE, W.; SCHULZE-OSTHOFF, K.; MIHM, S. et al. Functions of glutathione and glutathione disulfide in immunology and immunopathology. The FASEB Journal, v.8, p.1131-1138, 1994.

ERSKINE, R.J. Nutrition and mastitis. Update on bovine mastitis. Veterinary Clinics North American: Food Animal Practice, v.9, p.551-556, 1993.

ERSKINE, R.J.; EBERHART, R.J.; HUTCHIMON, L.J. Herd management and mastitis prevalence in high and low cell count dairy herds. Journal of American Veterinary Medical Association, v.190, 1411-1416, 1987.

FIALOVÀ, L.; MALBOHAN, I.; KALOUSOVA, M. et al. Oxidative stress and inflammation in pregnancy. Scandinavian Journal of Clinical and Laboratory Investigtion, v.66, 121-128, 2006.

FIVAZ, B.H.; HOBSON, C.; WELLINGTON, A.C. et al. Influence of selenium supplementation on helminth burdens of marginally deficient suckling Angora goat kids. Small Ruminant Research, v.10, p.75-79, 1993.
FLOHE, L.; GUNZLER, W.A.; SCHOCK, H.H. Glutathione peroxidase: a selenoenzyme. FEBS Letters, v.32, p.132-134, 1973.

FREI, B. Natural antioxidants in human health and disease. San Diego: Academic Press, 1994. 588p.

GAÁL, T.; RIBICZEYNÉ-SZABÓ, P.; STADLER, K. et al. Free radicals, lipid peroxidation and the antioxidant system in the blood of cows and newborn calves around calving. Comparative Biochemistry and Physiology Part B: Biochemistry and Molecular Biology, v.143, p.391-396, 2006.

GABAI, G.; TESTONI, S.; PICCININI, R. et al. Oxidative stress in primiparous cows in relation to dietary starch and the progress of lactation. Animal Science, v.79, p.99-108, 2004.

GATELLIER, P.; MERCIER, Y.; RENERRE, M. Effect of diet finishing mode (pasture or mixed diet) on antioxidant status of Charolais bovine meat. Meat Science, v.67, p.385-394, 2004.

GEORGIEVA, N.V. Oxidative stress as a factor of disrupted ecological oxidative balance in biological systems - a review. Bulgarian Journal of Veterinary Medicine, v.8, p.1-11, 2005.

GHISELLI, A.; SERAFINI, M.; MAIANI, G. et al. fluorescencebased method for measuring total plasma antioxidant capability. Free Radical Biology and Medicine, v.18, p.29-36, 1995.

GHISELLI, A.; SERAFINI, M.; NATELLA, F. et al. Total antioxidant capacity as a tool to assess redox status: critical view and experimental data. Free Radical Biology and Medicine, v.29, p.1106-1114, 2000.

GOFF, J.P.; STABEL, J.R. Decreased plasma retinol, alphatocopherol, and zinc concentration during the periparturient period: effect of milk fever. Journal of Dairy Science, v.73, p.3195-3199, 1990.

GOFF, W.L.; CARL JOHNSON, W.; WYATT, C.R. et al. Assessment of bovine mononuclear phagocytes and neutrophils for induced L-arginine-dependent nitric oxide production. Veterinary Immunology and Immunopathology, v.55, p.45-62, 1996. GRIFFITHS, H.R.; MøLLER, L.; BARTOSZ, G. et al. Biomarkers. Molecular Aspects of Medicine, v.23, p.101-208, 2002.

GU, B.; ZHU, Y.; ZHU, W. et al. Retinoid protects rats against neutrophil-induced oxidative stress in acute experimental mastitis. International Immunopharmacology, v.9, p.223229, 2009.

GUERIN, P.; EL MOUATASSIM, S.; MENEZO, Y. Oxidative stress and protection against reactive oxygen species in the preimplantation embryo and its surroundings. Human Reproduction Update, v.7, p.175-189, 2001.

HALLIWELL, B. Albumin - an important extracellular antioxidant. Biochemical Pharmacology, v.37, p.569-571, 1988.

HALLIWELL, B.; CHIRICO, S. Lipid peroxidation: its mechanism, measurement, and significance. American Journal of Clinical Nutrition, v.57, p.715S-725S, 1993.

HALLIWELL, B.; GUTTERIDGE, J.M.C. Free radicals in biology and medicine. Oxford: Oxford University Press, 1989. 543p.

HANSEN, P.J.; SOTO, P.; NATZKE, R.P. Mastitis and fertility in cattle - possible involvement of inflammation or immune activation in embryonic mortality. American Journal of Reproductive Immunology, v.51, p.294-301, 2004.

HERMES-LIMA, M.; STOREY, J.M.; STOREY, K.B. Antioxidants defenses and metabolic depression. The hypothesis of preparation for oxidative stress in land snails. Comparative Biochemistry and Physiology B: Biochemistry and Molecular Biology, v.120, p.437-448, 1988.

HOGAN, J.S.; SMITH, K.L.; WEISS, W.P. et al. Relationships among vitamin E, Selenium, and bovine blood neutrophils. Journal of Dairy Science, v.73, 2372-2378, 1990.

HOGAN, J.S.; WEISS, W.P.; SMITH, K.L. Role of vitamin E and selenium in host defense against mastitis. Journal of Dairy Science, v.76, 2795-2803, 1993.

HOPKINS, G.J.; ROBERTS, J.; EVANS, J.V. Red blood cell concentrations of reduced glutathione and potassium as 
biochemical markers of wool growth in Merino sheep. Journal of Agricultural Science, v.84, p.481-486, 1975. HOSTE, H.; TORRES-ACOSTA, J.F.; AGUILAR-CABALLERO, A.J. Nutrition; parasite interactions in goats: is immunoregulation involved in the control of gastrointestinal nematodes? Parasite Immunology, v.30, p.79-88, 2008.

HOSTETLER, C.E.; KINCAID, R.L.; MIRANDO, M.A. The role of essential trace elements in embryonic and fetal development in livestock. Veterinary Journal, v.166, p.125-139, 2003.

HUIE, R.E.; PADMAJA, S. The reaction of no with superoxide. Free Radical Research, v.18, p.195-199, 1993.

HUNTLEY, J.F.; PATTERSON, M.; MACKELLAR, A. et al. A comparison of the mast cell and eosinophil responses of sheep and goats to gastrointestinal nematode infections. Research in Veterinary Science, v.58, p.5-10, 1995.

INGVARTSEN, K.L.; ANDERSEN, J.B. Integration of metabolism and intake regulation: a review focusing on periparturient animals. Journal of Dairy Science, v.83, p.1573-1597, 2000.

JANERO, D.R. Malondialdehyde and thiobarbituric acid-reactivity as diagnostic indices of lipid peroxidation and peroxidative tissue injury. Free Radical Biology and Medicine, v.9, p.515-540, 1990.

JELINEK, P.D.; ELLIS, T.; WROTH, R.H. et al. The effect of selenium supplementation on immunity, and the establishment of an experimental Haemonchus contortus infection, in weaner Merino sheep fed a low selenium diet. Australian Veterinary Journal, v.65, p.214-217, 1988.

JOBGEN, W.S.; FRIED, S.K.; FU, W.J. et al. Regulatory role for the arginine-nitric oxide pathway in metabolism of energy substrates. The Journal of Nutritional Biochemistry, v.17, p.571-588, 2006

KALOUSOVÁ, M.; SKRHA, J.; ZIMA, T. Advanced glycation end products and advanced oxidation protein products in patients with diabetes mellitus. Physiological Research, v.51, p.597604, 2002.

KALOUSOVÁ, M.; ZIMA, T.; TESAR, V. et al. Advanced glycoxidation end products in chronic diseases-clinical chemistry and genetic background. Mutation Research/ Fundamental and Molecular Mechanisms of Mutagenesis. Inflammation, Cellular and Redox Signalling Mechanisms in Cancer and Degenerative Diseases, v.579, p.37-46, 2005.

KANEDA, H.; TAGUCHI, J.; OGASAWARA, K. et al. Increased level of advanced oxidation protein products in patients with coronary artery disease. Atherosclerosis, v.162, p.221-225, 2002.

KATO, H.; SUGINO, N.; TAKIGUCHI, S. et al. Roles of reactive oxygen species in the regulation of luteal function. Rev Reprod, v.2, p.81-83, 1997.

KEHRER, J.P.; LUND, L.G. Cellular reducing equivalents and oxidative stress. Free Radical Biology and Medicine, v.17, p.65-75, 1994.

KEHRER, J.P.; SMITH, C.V. Free radicals in biology: sources, reactivities, and roles in the etiology of human dieseases. In: FREI, B. (Ed.) Natural antioxidants in human health and diseases. San Diego: Academic Press, 1994. p.25-62.

KLECZKOWSKI, M.; KLUCINSKI, W.; SHAKTUR, A. et al. Concentration of ascorbic acid in the blood of cows with subclinical mastitis. Polish Journal of Veterinary Science, v.8, p.121-125, 2005.

KNAAPEN, A.M.; SEILER, F.; SCHILDERMAN, P.A.E.L. et al. Neutrophils cause oxidative DNA damage in alveolar epithelial cells. Free Radical Biology and Medicine, v.27, p.234-240, 1999.

KOMINE, K.-I.; KUROISHI, T.; KOMINE, Y. et al. Induction of nitric oxide production mediated by tumor necrosis factor alpha on staphylococcal enterotoxin c-stimulated bovine mammary gland cells. Clinical and Diagnostic Laboratory Immunology, v.11, p.203-210, 2004.
LEBLANC, S.J.; HERDT, T.H.; SEYMOUR, W.M. et al. Peripartum serum vitamin E, retinol, and beta-carotene in dairy cattle and their associations with disease. Journal of Dairy Science, v.87, p.609-619, 2004.

LIEBLER, D.C. The role of metabolism in the antioxidant function of vitamin E. doi:10.3109/10408449309117115. Critical Reviews in Toxicology, v.23, 147-169, 1993.

LIGHTBODY, J.H.; STEVENSON, L.M.; JACKSON, F. et al. Comparative aspects of plasma antioxidant status in sheep and goats, and the influence of experimental abomasal nematode infection. Journal of Comparative Pathology, v.124, p.192199, 2001.

LIU, S.M.; EADY, S.J. Glutathione: its implications for animal health, meat quality, and health benefits of consumersdoi:10.1071/AR05053. Australian Journal of Agricultural Research, v.56, p.775-780, 2005.

LIU, S.M.; MASTERS, D.G. Quantitative analysis of methionine and cysteine requirements for wool production of sheep. Animal Science, v.71, p.175-185, 2000.

LOHRKE, B.; VIERGUTZ, T.; KANITZ, W. et al. High milk yield in dairy cows associated with oxidant stress. Online Journal of Veterinary Research, v.8, p.70-78, 2004.

LYKKESFELDT, J. Determination of malondialdehyde as dithiobarbituric acid adduct in biological samples by hplc with fluorescence detection: comparison with ultraviolet-visible spectrophotometry. Clinical Chemistry, v.47, p.17251727, 2001.

LYKKESFELDT, J.; SVENDSEN, O. Oxidants and antioxidants in disease: Oxidative stress in farm animals. The Veterinary Journal, v.173, 502-511, 2007.

MACMICKING, J.; XIE, Q.-W.; NATHAN, C. Nitric oxide and macrophage function. Annual Review of Immunology, v.15, 323-350, 1997

MAKKAR, H.P.S.; FRANCIS, G.; BECKER, K. Bioactivity of phytochemicals in some lesser-known plants and their effects and potential applications in livestock and aquaculture production systems. Animal, v.1, p.1371-1391, 2007.

MARTIN, G.B.; KADOKAWA, H. "Clean, green and ethical” animal production. case study: reproductive efficiency in small ruminants. The Journal of Reproduction and Development, v.52, p.145-152, 2006.

MERLO, M.; BARBATO, O.; STEFANI, A. et al. Embryonic mortality and plasma advanced oxidation protein products (AOPP) increase in dairy cows. In: DAIRY RESEARCH FOUNDATION 'Current Topics in Dairy Production, SYMPOSIUM', 2008, Camden, Australia. Proceedings... Camden: 2008. p.49-53.

MERLO, M.; CELI, P.; BARBATO, O. et al. Relationships between oxidative status and pregnancy outcome in dairy cows. Animal Production in Australia, v.27, p.84, 2008.

MILLER, J.K.; BRZEZINSKA-SLEBODZINSKA, E.; MADSEN, F.C. Oxidative stress, antioxidants, and animal function. Journal of Dairy Science, v.76, p.2812-2823, 1993.

MILLER, N.J.; RICE-EVANS, C.; DAVIES, M.J. et al. A novel method for measuring antioxidant capacity and its application to monitoring the antioxidant status in premature neonates. Clinical Science, v.84, p.407-412, 1993.

MILNE, G.L.; MUSIEK, E.S.; MORROW, J.D. F2-isoprostanes as markers of oxidative stress in vivo: an overview. Biomarkers, v.10, p.10-23, 2005.

MOILANEN, E.; VAPAATALO, H. Nitric oxide in inflammation and immune response. Annals of Medicine, v.27, p.359-367, 1995.

MORAN, L.K.; GUTTERIDGE, J.; QUINLAN, G.J. Thiols in cellular redox signalling and control. Current Medicinal Chemistry, v.8, p.763, 2001.

MUKHERJEE, R. Selenium and vitamin $E$ increases polymorphonuclear cell phagocytosis and antioxidant levels during acute mastitis in riverine buffaloes. Veterinary Research Communications, v.32, p.305-313, 2008. 
MUSICKI, B.; ATEN, R.; BEHRMAN, H. Inhibition of protein synthesis and hormone-sensitive steroidogenesis in response to hydrogen peroxide in rat luteal cells. Endocrinology, v.134, p.588-595, 1994.

NARESH, R.; DWIVEDI, S.K.; SWARUP, D. et al. Evaluation of ascorbic acid treatment in clinical and subclinical mastitis of Indian dairy cows. Asian-Australasian Journal of Animal Science, v.15, p.905-911, 2002.

NORMAN, J.E.; THOMSON, A.J.; TELFER, J.F. et al. Myometrial constitutive nitric oxide synthase expression is increased during human pregnancy. Molecular Human Reproduction, v.5, p.175-181, 1999

NOTEBAERT, S.; DEMON, D.; VANDEN BERGHE, T. et al. Inflammatory mediators in Escherichia coli-induced mastitis in mice. Comparative Immunology, Microbiology and Infectious Diseases, v.31, 551-565, 2008.

NOYAN, T.; GÜLER, A.; SEKEROGLU, M.R. et al. Serum advanced oxidation protein products, myeloperoxidase and ascorbic acid in pre-eclampsia and eclampsia. Australian and New Zealand Journal of Obstetrics and Gynaecology, v.46, p.486-491, 2006.

OKAMOTO, T.; AKAIKE, T.; NAGANO, T. et al. Activation of human neutrophil procollagenase by nitrogen dioxide and peroxynitrite: a novel mechanism for procollagenase activation involving nitric oxide. Archives of Biochemistry and Biophysics, v.342, 261-274, 1997.

PAULA-LOPES, F.F.; AL-KATANANI, Y.M.; MAJEWSKI, A.C. et al. Manipulation of antioxidant status fails to improve fertility of lactating cows or survival of heat-shocked embryos. Journal of Dairy Science, v.86, 2343-2351. 2003.

PEDERNERA, M.; CELI, P.; GARCÍA, S.C. et al. Effect of diet, energy balance and milk production on oxidative stress in early lactating dairy cows fed on a predominantly grazed pasturediet. The Veterinary Journal, 2009 (in press).

PERL, A.; GERGELY, P.; PUSKAS, F. et al. Metabolic switches of T-cell activation and apoptosis. Antioxidants \& Redox Signaling, v.4, p.427-443, 2002.

PETRECCIA, D.C.; NAUSEEF, W.M.; CLARK, R.A. Respiratory burst of normal human eosinophils. Journal of Leukocyte Biology, v.41, p.283-288, 1987.

PREGEL, P.; BOLLO, E.; CANNIZZO, F. et al. Antioxidant capacity as a reliable marker of stress in dairy calves transported by road. The Veterinary Record, v.156, p.53-54, 2005.

RANJAN, R.; SWARUP, D.; NARESH, R. et al. Enhanced erythrocytic lipid peroxides and reduced plasma ascorbic acid, and alteration in blood trace elements level in dairy cows with mastitis. Veterinary Research Communications, v.29, p.7-34, 2005.

REILlY, P.M.; SCHILLER, H.J.; BULKLEY, G.B. Pharmacologic approach to tissue injury mediated by free radicals and other reactive oxygen metabolites. The American Journal of Surgery, v.161, p.488-503, 1991.

REYNOLDS, L.P.; BOROWICZ, P.P.; VONNAHME, K.A. et al. Placental angiogenesis in sheep models of compromised pregnancy. The Journal of Physiology, v.565, p.43-58, 2005.

RIOLLET, C.; RAINARD, P.; POUTREL, B. Differential induction of complement fragment c5a and inflammatory cytokines during intramammary infections with Escherichia coli and Staphylococcus aureus. Clinical and Diagnostic Laboratory Immunology, v.7, p.161-167, 2000.

RIVERA, M.T.; SOUZA, A.P.D.; ARAUJO-JORGE, T.C. et al. Trace elements, innate immune response and parasites. Clinical Chemistry and Laboratory Medicine, v.41, 1020-1025, 2003.

RiZZO, A.; MUTINATI, M.; SPEDICATO, M. et al. First demonstration of an increased serum level of reactive oxygen species during the peripartal period in the ewes. Immunopharmacology and Immunotoxicology, v.30, p.741-746, 2008.
ROBSON, S.; PLANT, J.W. Selenium deficiency in sheep. Primefact 471 (NSW Department of Primary Industries), 2007. 5p.

ROSSELLI, M.; DUBEY, R.; IMTHURN, B. et al. Effects of nitric oxide on human spermatozoa: evidence that nitric oxide decreases sperm motility and induces sperm toxicity. Human Reproduction, v.10, p.1786-1790, 1995.

ROSSELLI, M.; DUBEY, R.; ROSSELLI, M. Identification of nitric oxide synthase in human and bovine oviduct. Molecular Human Reproduction, v.2, p.607-612, 1996.

ROSSELLI, M.; KELLER, P.; DUBEY, R. Role of nitric oxide in the biology, physiology and pathophysiology of reproduction. Human Reproduction Update, v.4, p.3-24, 1998.

RUEDA, B.; TILLY, K.; HANSEN, T. et al. Expression of superoxide dismutase, catalase and glutathione peroxidase in the bovine corpus luteum: evidence supporting a role for oxidative stress in luteolysis. Endocrine, v.3, p.227-232, 1995.

SAKATANI, M.; YAMANAKA, K.; KOBAYASHI, S. et al. Heat shock-derived reactive oxygen species induce embryonic mortality in in vitro early stage bovine embryos. Journal of Reproduction and Development, v.54, p.496-501, 2008.

SAUBERLICH, H.E. Pharmacology of vitamin C. Annual Review Nutrition, v.14, p.371-391, 1994.

SAWADA, M.; CARLSON, J. Studies on the mechanism controlling generation of superoxide radical in luteinized rat ovaries during regression. doi: 10.1210/en.135.4.1645. Endocrinology, v.135, p.1645-1650, 1994.

SAWADA, M.; CARLSON, J.C. Rapid plasma membrane changes in superoxide radical formation, fluidity, and phospholipase A2 activity in the corpus luteum of the rat during induction of luteolysis. Endocrinology, v.128, p.2992-2998, 1991..

SCALETTI, R.W.; TRAMMELL, D.S.; SMITH, B.A. et al. Role of dietary copper in enhancing resistance to escherichia coli mastitis. Journal of Dairy Science, v.86, p.1240-1249, 2003.

SELKIRK, M.E.; SMITH, V.P.; THOMAS, G.R.et al. Resistance of filarial nematode parasites to oxidative stress. International Journal for Parasitology, v.28, p.1315-1332, 1998.

SHARMA, R.; AGARWAL, A. Role of reactive oxygen species in gynecologic diseases. Reproductive Medicine and Biology, v.3, p.177-199, 2004.

SHI, W.; MEININGER, C.; HAYNES, T. et al. Regulation of tetrahydrobiopterin synthesis and bioavailability in endothelial cells. Cell Biochemistry and Biophysics, v.41, p.415-433, 2004.

SHI, X.Y.; HOU, F.F.; NIU, H.X. et al. Advanced oxidation protein products promote inflammation in diabetic kidney through activation of renal nicotinamide adenine dinucleotide phosphate oxidase. Endocrinology, v.149, p.1829-1839, 2008.

SHIMAMURA, K.; SUGINO, N.; YOSHIDA, Y. et al. Changes in lipid peroxide and antioxidant enzyme activities in corpora lutea during pseudopregnancy in rats. Journal of Reproduction and Fertility, v.105, p.253-257, 1995.

SMITH, A.; MADDEN, K.B.; YEUNG, K.J.A. et al. Deficiencies in selenium and/or vitamin e lower the resistance of mice to heligmosomoides polygyrus infections. The Journal of Nutrition, v.35, p.830-836, 2005.

SMITH, J.A. Neutrophils, host defense, and inflammation: a doubleedged sword. Journal of Leukocyte Biology, v.56, p.672-686, 1994.

SMITH, K.L.; HARRISON, J.H.; HANCOCK, D.D. et al. Effect of vitamin $\mathrm{E}$ and selenium supplementation on incidence of clinical mastitis and duration of clinical symptoms. Journal of Dairy Science, v.67, p.1293-1300, 1984.

SMITH, K.L.; HOGAN, J.S.; WEISS, W.P. Dietary vitamin E and selenium affect mastitis and milk quality. Journal of Animal Science, v.75, 1659-1665, 1997.

SORIANI, M.; PIETRAFORTE, D.; MiNETTI, M. Antioxidant potential of anaerobic human plasma: role of serum albumin and thiols as scavengers of carbon radicals. Archives of Biochemistry and Biophysics, v.312, p.180-188, 1994. 
SPEARS, J.W.; WEISS, W.P. Role of antioxidants and trace elements in health and immunity of transition dairy cows. The Veterinary Journal, Production Diseases of the Transition Cow, v.176, 70-76, 2008.

SUGINO, N. Roles of reactive oxygen species in the corpus luteum. Animal Science Journal, v.77, p.556-565, 2006.

TAKAHASHI, M.; KEICHO, K.; TAKAHASHI, H. et al. Effect of oxidative stress on development and DNA damage in in-vitro cultured bovine embryos by comet assay. Theriogenology, v.54, p.137-145, 2000.

TANAKA, M.; MIYAZAKI, T.; TANIGAKI, S. et al. Participation of reactive oxygen species in PGF2alpha-induced apoptosis in rat luteal cells. Journal of Reproduction and Fertility, v.120, 239-245, 2000.

TORRES-ACOSTA, J.F.J.; HOSTE, H. Alternative or improved methods to limit gastro-intestinal parasitism in grazing sheep and goats. Small Ruminant Research, v.77, p.159-173, 2008.

TROUT, J.P.; MCDOWELL, L.R.; HANSEN, P.J. Characteristics of the estrous cycle and antioxidant status of lactating Holstein cows exposed to heat stress. Journal of Dairy Science, v.81, p.1244-1250, 1998.

TURRENS, J.F. Oxidative stress and antioxidant defences: a target for the treatment of diseases caused by parasitic protozoa. Molecular Aspects of Medicine, Oxidative Stress in Aging and Disease, v.25, 211-220, 2004.

TÜZÜN, A.; ERDIL, A.; INAL, V. et al. Oxidative stress and antioxidant capacity in patients with inflammatory bowel disease. Clinical Biochemistry, v.35, p.569-572, 2002.

UELAND, P.M.; MANSOOR, M.A.; GUTTORMSEN, A.B. et al. Reduced, oxidized and protein-bound forms of homocysteine and other aminothiols in plasma comprise the redox thiol status-a possible element of the extracellular antioxidant defense system. The Journal of Nutrition, v.126, p.1281S-1284, 1996.

UPCROFT, P.; UPCROFT, J.A. Drug targets and mechanisms of resistance in the anaerobic protozoa. Clinical Microbiology Reviews, v.14, p.150-164, 2001.

VAN HOUTERT, M.F.J.; SYKES, A.R. Implications of nutrition for the ability of ruminants to withstand gastrointestinal nematode infections. International Journal for Parasitology, v.26, p.1151-1167, 1996.

VEGA, M.; CASTILLO, T.; RETAMALES, I. et al. Steroidogenic capacity and oxidative stress-related parameters in human luteal cell regression. Free Radical Biology and Medicine, v.17, p.493-499, 1994.

VENDITTI, P.; MEO, S. Thyroid hormone-induced oxidative stress. Cellular and Molecular Life Sciences (CMLS), v.63, p.414434, 2006.

VINCENT, H.K.; INNES, K.E.; VINCENT, K.R. Oxidative stress and potential interventions to reduce oxidative stress in overweight and obesity. Diabetes, Obesity and Metabolism, v.9, p.813-839, 2007.
WANG, P.G.; XIAN, M.; TANG, X. et al. Nitric oxide donors: chemical activities and biological applications. Chemical Reviews, v.102, 1091-1134, 2002.

WEISS, W.P.; HOGAN, J.S.; SMITH, K.L. Changes in Vitamin C Concentrations in plasma and milk from dairy cows after an intramammary infusion of Escherichia coli. Journal of Dairy Science, v.87, p.32-37, 2004.

WEISS, W.P.; HOGAN, J.S.; TODHUNTER, D.A. et al. Effect of vitamin $E$ supplementation in diets with a low concentration of selenium on mammary gland health of dairy cows. Journal of Dairy Science, v.80, 1728-1737, 1997.

WEISS, W.P.; SMITH, K.L.; HOGAN, J.S. et al. Effect of forage to concentrate ratio on disappearance of vitamins a and $e$ during in vitro ruminal fermentation. Journal of Dairy Science, v.78, p.1837-1842, 1995.

WHELAN, B.R.; NJ, B.; PETER, D.W. Selenium fertilizers for pastures grazed by sheep. 2. Wool and liveweight responses to selenium. Australian Journal of Agricultural Research, v.45, p.877-887, 1994.

WHITE, C.L.; REWELL, L. Vitamin E and selenium status of sheep during autumn in Western Australia and its relationship to the incidence of apparent white muscle disease. Australian Journal of Experimental Agriculture, v.47, p.535-543, 2007.

WILLIAMS, A.J. Metabolism of cysteine by Merino sheep genetically different in wool production. 4. Rates if entry of cystine in to plasma, measured with a single intravenous infection of L-[34S] cystine, and the subsequent incorporation of 35S into wool fibres. Australian Journal of Biological Sciences, v.29, p.513-524, 1976.

WITKO-SARSAT, V.; FRIEDLANDER, M.; KHOA, T.N. et al. Advanced oxidation protein products as novel mediators of inflammation and monocyte activation in chronic renal failure1, 2. The Journal of Immunology, v.161, p.2524-2532, 1998.

WITKO-SARSAT, V.; NGUYEN-KHOA, T.; JUNGERS, P. et al. Advanced oxidation protein products as a novel molecular basis of oxidative stress in uraemia. Nephrology Dialysis Transplantation, v.14, p.76-78, 1999.

WOOLASTON, R.R.; BAKER, R.L. Prospects of breeding small ruminants for resistance to internal parasites. International Journal for Parasitology, v.26, p.845-855, 1996.

WU, G.; FANG, Y.-Z.; YANG, S. et al. Glutathione metabolism and its implications for health. Journal of Nutrition, v.134, 489492, 2004.

YAMASHITA, T.; SOMEYA, A. Comparative study on the stimulation of superoxide production in guinea-pig eosinophils by the calcium ionophore A23187. Biochimica et Biophysica Acta (BBA) - Molecular Cell Research, v.927, p.359-365, 1987. 